\title{
Analisis Optimalisasi Benefit Aset Keuangan Nelayan Ubur-Ubur dalam Mewujudkan Kesejahteraan
}

\author{
Sri Rahayu*, I Putu Gede Diatmika \\ Samawa University, Jln. Bay Pass Sering Kabupaten Sumbawa, NTB, Indonesia \\ Universitas Pendidikan Ganesha, Jalan Udayana 11 Singaraja, Bali, Indonesia \\ "(rahmaayu272@gmail.com)
}

\section{Riwayat Artikel: \\ Tanggal diajukan: \\ 21 Februari 2021 \\ Tanggal diterima: \\ 20 Juni 2021}

Tanggal dipublikasi daring: 25 Juni 2021

Kata kunci: kesejahteraan; nelayan optimalisasi benefit

\section{Pengutipan:}

Rahayu, Sri \& Diatmika, I Putu Gede. (2021). Analisis Optimalisasi Benefit Aset Keuangan Nelayan UburUbur dalam Mewujudkan Kesejahteraan. JIA (Jurnal Ilmiah Akuntansi), Vol. 6, No. 1, Hal: 181-199.

Keywords: optimization of benefits; jellyfish fishermen; welfare

\section{ABSTRAK}

Kemunculan Ubur-Ubur di pulau Teluk Saleh Kabupaten Sumbawa, merupakan sebuah peluang untuk mengembangkan produk ini bukan hanya mengekspor material baku, akan tetapi berupa material olahan agar memiliki nilai tambah yang lebih besar dari sekedar bahan baku. Tujuan penelitian ini untuk menganalisis optimalisasi benefit usaha nelayan Ubur- Ubur dalam mewujudkan kesejahteraan. Jenis penelitian ini adalah penelitian deskriptif dengan metode survey melalui pendekatan kualitatif. Adapun Teknik analisis data melalui reduksi data, penyajian data dan penarikan kesimpulan. Sejumlah besar nelayan sudah mendapatkan benefit dari usaha penangkapan Ubur- Ubur di pulau Teluk Saleh. Pemanfaatan Ubur- Ubur di Teluk saleh dapat memberi dampak positif karena dianggap sebagai hama penyengat dapat menjadi komoditas ekspor Teluk Saleh yang mempunyai nilai dan harga jual yang tinggi, terlebih lagi hasil laut di Teluk Saleh cukup berlimpah, sehingga menjadikan masyarakat nelayan pulau Teluk Saleh Kabupaten Sumbawa merasa berkecukupan dan berimplikasi pada peningkatan kesejahteraan nelayan Ubur-ubur Teluk Saleh.

ABSTRACT
The appearance of Jellyfish on Teluk Saleh Island,
Sumbawa Regency, is an opportunity to develop this
product, not only exporting raw materials, but also in the
form of processed materials so that they have a greater
added value than just raw materials. The purpose of this
study is to analyze the optimization of the business benefits
of Jellyfish fishermen in realizing prosperity. This type of
research is descriptive research with survey methods
through a qualitative approach. The data analysis
technique is through data reduction, data presentation and
conclusion drawing. A large number of fishermen have
benefited from the business of catching jellyfish on the
island of Teluk Saleh. Utilization of Jellyfish in Saleh Bay
can have a positive impact because it is considered a
stinging pest and can become Saleh Bay's export
commodity which has a high selling value and price. feel
self-sufficient and have implications for improving the
welfare of Jellyfish fishermen in Teluk Saleh.

\section{ABSTRACT}

The appearance of Jellyfish on Teluk Saleh Island, form of processed materials so that they have a greater added value than just raw materials. The purpose of this study is to analyze the optimization of the business benefits of Jellyfish fishermen in realizing prosperity. This type of research is descriptive research with survey methods through a qualitative approach. The data analysis technique is through data reduction, data presentation and conclusion drawing. A large number of fishermen have benefited from the business of catching jellyfish on the island of Teluk Saleh. Utilization of Jellyfish in Saleh Bay can have a positive impact because it is considered a stinging pest and can become Saleh Bay's export self-sufficient and have implications for improving the welfare of Jellyfish fishermen in Teluk Saleh. 


\section{PENDAHULUAN}

Peningkatan

kesejahteraan

masyarakat pesisir salah satu kecenderungan baru dalam paradigma pembangunan. Setelah sekian lama wilayah laut dan pesisir menjadi wilayah yang terabaikan dan dilupakan dalam pembangunan. Secara normatif, seharusnya masyarakat pesisir merupakan masyarakat yang sejahtera karena potensi sumber daya alamnya yang besar. Ada banyak kegunaan yang mampu dieksplorasi dari sumber kelautan yang dimiliki, salah satunya memberdayakan masyarakat pesisir sebagai konsumen utama yang akan memanfaatkan sektor kelautan yang ada.

Dinas Kelautan dan Perikanan, (2003) menegaskan bahwa berbagai kegiatan diarahkan ke wilayah pesisir karena memiliki sumber daya alam yang sangat menarik. Negara Kesatuan Republik Indonesia merupakan negara kelautan. Indonesia memiliki 17.506 pulau besar dan kecil, dengan garis pantai mencapai $81.000 \mathrm{~km}$ dan merupakan negara yang memiliki garis pantai terpanjang kedua di dunia. Sebagian masyarakat Kelurahan Teluk Saleh bermata pencaharian sebagai nelayan, ketergantungan nelayan terhadap hasil laut merupakan salah satu cara nelayan bertahan hidup.
Menurut Undang- Undang No. 31 Tahun 2004 tentang perikanan, masyarakat nelayan adalah masyarakat yang memiliki mata pencaharian yaitu mencari ikan untuk memenuhi kebutuhan hidup sehari- hari.

Andarsari \& Ningtyas (2019) menyatakan bahwa Pemahaman literasi keuangan secara ekonomi sangat penting, baik itu dalam mengalokasikan pendapatan yang diperoleh maupun pengelolaan keuangan dalam upaya kesejahteraan. Hasil penelitian Indrayani (2020) menunjukkan bahwa suatu usaha dapat mengoptimalkan keuntungannya atau keuangannya apabila mampu menjalankan usahanya dengan baik maka dapat mengoptimalkan benefitnya.

Pada kenyataannya hingga saat ini sebagian besar masyarakat pesisir masih merupakan bagian dari masyarakat yang tertinggal dibandingkan dengan kelompok masyarakat lainnya (Departemen Kelautan dan Perikanan., 2000). Salah satu ciri umum yang melekat pada masyarakat pesisir adalah permodalan yang lemah, 
padahal permodalan merupakan unsur utama dalam mendukung peningkatan produksi dan taraf hidup bagi masyarakat pesisir. Meskipun cukup potensial namun tingkat kesejahteraan masyarakat kawasan pesisir relatif masih rendah jika dibandingkan dengan kelompok masyarakat lain. Begitu banyak kendala yang dihadapi masyarakat di kawasan pesisir diantaranya adalah kebijakan pemerintah, kualitas pelayanan, pembangunan akses modal, pembangunan sarana dan prasarana, minimnya alat tangkap dan faktor cuaca yang tidak menentu. Kekurangan modal ini juga sangat mengurangi aktivitas usaha masyarakat pesisir yang ditujukan untuk meningkatkan kesejahteraan melalui peningkatan pendapatan (Kasryno, 2004).

Perekonomian masyarakat Teluk Saleh Kabupaten Sumbawa sangat bergantung pada hasil tangkapan laut. Pada saat musim angin dan ombak besar tidak jarang pula nelayan Teluk Saleh pulang dengan tangan kosong, namun pada saat cuaca mendukung nelayan Teluk Saleh harus bersaing dalam perebutan sumberdaya laut, sehingga pemenuhan standar hidup layak sangat sulit untuk dicapai. Kondisi tersebut semakin membuat nelayan pesisir terus berada dalam lingkaran kemiskinan setiap tahunnya. Pada umumnya masyarakat nelayan Teluk Saleh belum sepenuhnya tersentuh oleh teknologi modern, sehingga kualitas sumber daya manusia masih rendah yang dapat mempengaruhi tingkat produktivitas hasil tangkapan.

Tingkat pendidikan nelayan berbanding lurus dengan teknologi yang dapat dihasilkan oleh nelayan, dalam hal ini adalah teknologi dibidang penangkapan dan budidaya. Kebanyakan tingkat pendidikan masyarakat hanya sebatas lulusan Sekolah Dasar. Pendidikan sangat mempengaruhi pola pikir nelayan dalam pengambilan keputusan, seperti dalam hal yang terkait dengan tingkat adopsi teknologi yang akan diterapkan dalam menangani hasil tangkapan laut. Pada sisi lain ikan hasil tangkapan cepat mengalami proses pembusukan dibandingkan 
dengan makanan lain, hal itu disebabkan oleh adanya bakteri dan perubahan kimiawi pada ikan. Oleh karena itu, diperlukan teknologi pengawetan ikan yang baik. Selama ini, nelayan hanya mengandalkan boks es untuk mengawetkan hasil tangkapannya dan langsung menjual hasil tangkapannya kepada pengepul. Disamping itu kurangnya kesempatan berusaha, kurangnya akses terhadap informasi, permodalan, teknologi, budaya dan gaya hidup yang cenderung boros, menyebabkan posisi tawar masyarakat nelayan Teluk Saleh di Kabupaten Sumbawa semakin lemah.

Teluk Saleh Pulau Sumbawa memiliki potensi sumberdaya hayati laut (perikanan) yang potensial untuk dimanfaatkan oleh nelayan setempat. Ubur-ubur yang awalnya sebagai hama pengganggu biota laut lainnya dan penghambat penangkapan ikan metode pukat dan pancing kini menjadi tangkapan target sejak tahun 2006 (Asrial et al., 2015). Di Kepulauan Teluk Saleh Kabupaten Sumbawa pada saat musim Ubur- Ubur kurang lebih tepatnya pada akhir dan awal tahun, bersikar antara bulan November, Desember, Januari hingga Februari mengalami panen Ubur-Ubur. Pada bulan-bulan tersebut Ubur-Ubur naik kepermukaan lautan sehingga dapat mengganggu aktivitas nelayan dalam menangkap ikan di lautan. Pada awalnya nelayan Teluk Saleh merasa terganggu dengan munculnya Ubur-Ubur, karena aktivitas melaut nelayan Teluk Saleh yang terganggu, akan tetapi banyaknya permintaan akan Ubur-Ubur, nelayan Teluk Saleh di Kabupaten Sumbawa mulai memanfaatkan Ubur-Ubur tersebut sebagai ladang mencari dan menambah pendapatan mereka, Ubur-Ubur yang tadinya dianggap sebagai "Hama" oleh masyarakat nelayan Teluk Saleh, kini justru menjadi ladang rizki nelayan Teluk Saleh. Hampir semua nelayan Teluk Saleh menangkap Ubur-Ubur ketika musim Ubur-Ubur tiba. Hal ini dapat menambah pendapatan nelayan Ubur-Ubur Teluk Saleh.

Namun demikian pola konsumsi masyarakat nelayan Teluk Saleh yang cenderung tinggi 
dapat

mempengaruhi

kesejahteraan rumah tangga

nelayan Teluk Saleh, sehingga

perlu adanya strategi pada manajemen usaha nelayan Teluk

Saleh dalam upaya mewujudkan kesejahteraannya.

Tiga kategori nelayan memiliki tingkat perekonomian yang berbeda. Perbedaan perekonomian tersebut menjadikan nelayan sebagai anggota masyarakat yang tertinggal dan memiliki kesenjangan penghidupan. Beberapa faktor yang menyebabkan hal tersebut seperti strategi yang digunakan dalam pengelolaan potensi kelautan, perbedaan kepemilikan aset, pendapatan, pengeluaran yang dilakukan oleh masyarakat, perubahan musim melaut yang disebabkan oleh cuaca dan sebagian nelayan telah merasa puas dengan kehidupannya sebagai nelayan, hal ini lah yang memunculkan kesenjangan kehidupan pada masyarakat nelayan. Riefsa (2014) menyatakan bahwa pemanfaatan sumberdaya ikan dan kelautan berperan penting dalam upaya peningkatan kesejahteraan masyarakat pesisir khususnya nelayan.

Manfaat yang diperoleh antara lain adanya penyediaan bahan kebutuhan dasar, peningkatan penghasilan, kesempatan kerja, perolehan devisa, dan pembangunan daerah. Disamping itu perlu adanya strategi usaha nelayan dalam mewujudkan kesejahteraan nelayan. Untuk menutupi kecenderungan menurunnya sumber daya alam, modal sosial merupakan sebuah alternatif dalam rangka meningkatkan kekuatan pelakupelaku ekonomi serta dapat meningkatkan efisiensi. Modal sosial seperti norma, jaringan, dan kepercayaan, dalam suatu komunitas dapat menjadikan anggota di dalamnya lebih berdaya (Gunawan, 2010).

Kesejahteraan tercipta bukan saja kesejahteraan secara ekonomis dan material tetapi juga mencakup kesejahteraan lahir dan batin serta kesejahteraan materiil dan sepirituil. Kesejahteraan tidak hanya dinilai dari besar kecilnya pendapatan tapi lebih dari pada itu, seseorang 
dikatakan sejahtera jika mampu terpenuhi kebutuhan secara lahir dan batin (Badan Pusat Statistik, 2015).

Asset keuangan yang dimiliki masyarakat nelayan di Teluk Saleh berasal dari sumberdaya yang dikuasai dari aktivitas melaut/ penangkapan ikan/Ubur-ubur yang diharapkan dapat mengoptimalisasi benefit dan asset tersebut memiliki nilai yang berdampak pada peningkatan kesejahteraan. Adapun tujuan penelitian ini adalah untuk menganalisis optimalisasi benefit nelayan Ubur-ubur Teluk Saleh dalam mewujudkan kesejahteraan di Kabupaten Sumbawa.

\section{TELAAH LITERATUR}

\section{Konsep Aset}

Asset dalam SAK ETAP 2009 yaitu sumber daya yang dikuasai oleh entitas dan merupakan akibat dari suatu kegiatan yang manfaatnya secara ekonomi dirasakan dan diharapkan dapat diakui dalam neraca serta asset tersebut memiliki nilai atau biaya yang dapat diukur benefitnya secara ekonomi (Qashidi, 2019).
Dalam SAK ETAP 2013 juga dinyatakan bahwa entitas harus menerapkan kriteria pengakuan dalam menentukan asset tetap, entitas harus mengakui biaya perolehan asset tetap jika benefitnya secara ekonomi yang berkaitan dengan pos asset akan mengalir dari entitas dan pos asset tersebut memiliki nilai benefit secara ekonomi (Qashidi, 2019).

Asset tetap diukur berdasarkan biaya perolehan, karena dalam SAK ETAP penilaian asset berdasarkan biaya perolehan. Selama mendapatkan benefit, entitas dianjurkan untuk mengalokasikan jumlah asset yang dapat disusutkan.

Persediaan adalah salah satu asset lancar yang berpengaruh terhadap benefit. Hal ini disebabkan bahwa persediaan merupakan aspek utama dalam menentukan dan mengoptimalisasi benefit secara ekonomi dari sebuah kegiatan usaha.

Ubur- Ubur pada dasarnya memiliki banyak manfaat, yaitu; dapat dijadikan sebagai obat dan memiliki potensi yang baik untuk dijadikan sebagai sumber devisa Negara, melalui jalur ekspor, 
sehingga dapat meningkatkan perekonomian nelayan. UburUbur dapat juga dimanfaatkan untuk kepentingan pembuatan makanan dan industri. Umumnya Ubur- Ubur dianggap binatang beracun, namun ada beberapa jenis yang dapat dikonsumsi misalnya Ubur-Ubur pantai (Aurelia sp.) (Solihat, 2004).

Asset biologis sebagai asset yang dapat bergerak; hewan, binatang dan tanaman hidup dengan tujuan untuk dijual dan untuk menghasilkan produk serta untuk menambah jumlah asset biologis. Ubur-ubur ada yang dapat dipanen dan ada yang belum dapat dipanen. IAS-41 2008 menyatakan bahwa asset biologis dewasa adalah asset biologis yang telah mmenuhi kriteria untuk dipanen dan asset biologis yang belum dewasa adalah asset biologis yang belum dapat dipanen dan belum dapat menghasilkan benefit.

\section{Konsep Kesejahteraan}

Rambe (2004) menyatakan bahwa kesejahteraan adalah suatu tata kehidupan dan penghidupan sosial, material, maupun spiritual yang diliputi rasa keselamatan, kesusilaan dan ketentraman lahir batin yang memungkinkan setiap warga negara untuk mengadakan usaha-usaha pemenuhan kebutuhan jasmani, rohani dan sosial yang sebaik-baiknya bagi diri, rumah tangga serta masyarakat.

Berdasarkan tingkat ketergantungan dari dimensi standar hidup (standard of living) masyarakat, maka tingkat kesejahteraan masyarakat dapat dibedakan ke dalam satu sistem kesejahteraan (well-being) dan dua subsistem, yakni: 1) subsistem sosial; dan 2) subsistem ekonomi, dengan beberapa faktor di antaranya kesejahteraan manusia, kesejahteraan sosial, konsumsi, tingkat kemiskinan dan aktivitas ekonomi.

Bronsteen et al. (2010), menyatakan bentuk kepuasan obyektif dan kebahagiaan subyektif maka peningkatan kualitas hidup manusia menunjukkan peningkatan kesejahteraan. Secara makro kesejahteraan rumah tangga dapat didekati dengan hukum Engel yang menyatakan bahwa pengeluaran makanan 
terhadap pengeluaran rumah tangga akan semakin berkurang dengan pendapatan yang meningkat. Pada kondisi harga barang dan selera masyarakat tetap maka peningkatan pendapatan menunjukkan kesejahteraan masyarakat meningkat.

\section{METODE}

Penelitian ini merupakan jenis penelitian deskriptif dan metode utama yang digunakan yaitu metode survey dengan pendekatan kualitatif. Metode penelitian survey adalah metode penelitian yang membantu dalam pengamatan, peneliti memilih sampel dari populasi menggunakan wawancara dan kuesioner yang sudah baku/ standar (Morissan, 2012). Lokasi penelitian terletak di Pulau Teluk Saleh Kecamatan Empang Kabupaten Sumbawa. Responden dalam penelitian ini adalah rumah tangga nelayan Ubur-Ubur di Pulau Teluk Saleh, hampir semua nelayan di Pulau Teluk Saleh merupakan nelayan UburUbur.
Penentuan sampel pada penelitian ini menggunakan teknik Simple Random Sampling. Random yang dimaksudkan dalam pengambilan sampel adalah responden yang ditemukan pertama secara acak tanpa memilih responden terlebih dahulu, namun responden tersebut memiliki kategori yang sama yaitu sebagai nelayan UburUbur.

Penelitian ini menggunakan data primer dan data sekunder. Proses pengumpulan data menggunakan beberapa teknik antara lain observasi, dokumentasi, wawancara, kuesioner dan pengumpulan data sekunder yaitu data jumlah nelayan di pulau Teluk Saleh. Observasi dilakukan dalam penelitian ini bertujuan untuk mengetahui kondisi wilayah penelitian yang dilakukan di Pulau Teluk Saleh.

Wawancara dan kuesioner dilakukan untuk mendapatkan data primer mengenai strategi usaha nelayan Ubur-Ubur di Pulau Teluk Saleh dalam mewujudkan kesejahteraan. Adanya prospek pemasaran bagi 
produk perikanan, dengan adanya sistem pengelolaan usaha yang baik dan benar dengan tujuan untuk mewujudkan pencapaian tujuan yang diindikasikan pada memaksimalkan kekuatan yang dimiliki oleh rumah tangga nelayan dalam rangka mengantisipasi adanya ancaman dari luar lingkungan dan meminimalisir kelemahan yang dimiliki oleh rumah tangga nelayan dalam memanfaatkan adanya peluang yang mungkin dapat dilakukan.

Adapun strategi usaha yang akan dikaji dalam penelitian ini mengacu pada Manullang (2012). Pertama, Sumber Daya Manusia (SDM) sebagai manusia yang bekerja, dalam penelitian ini adalah nelayan Ubur- Ubur. Nelayan juga harus memiliki kemampuan dan strategi dalam menangkap UburUbur, karena cuaca yang tidak mendukung juga akan berpengaruh pada hasil tangkapan, banyaknya nelayan Ubur-Ubur sebagai pesaing juga menjadi penentu jumlah hasil tangkapan sehingga nelayan juga harus memiliki SDM dalam menangkap Ubur-Ubur.
Kedua, Modal, dalam usaha menangkap Ubur- Ubur juga dibutuhkan modal, karena usaha melaut tentu membutuhkan modal yang tidak sedikit, fasilitas, sarana prasarana pendukung aktivitas melaut harus memadai sehingga nelayan Ubur- Ubur mendapatkan hasil tangkapan yang banyak. (3) Karakteristik Produk, dalam hal ini jenis Ubur- Ubur juga akan berpengaruh pada hasil penjualan dan menjadi nilai tambah bagi nelayan (Umar, 2008). Adapun kerangka konsep penelitian ini dapat dilihat pada Gambar berikut.

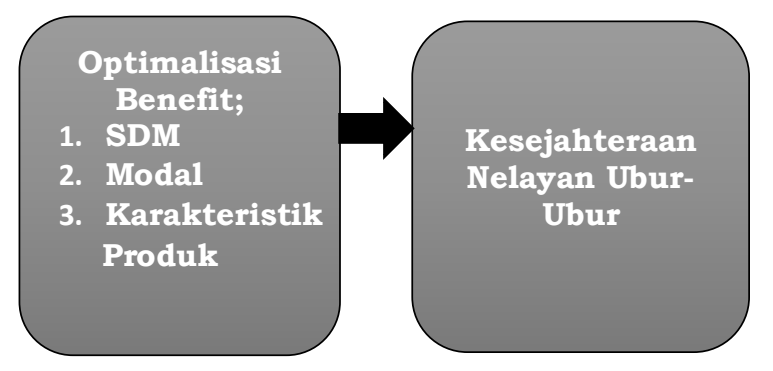

Gambar. Kerangka Konsep

\section{HASIL DAN PEMBAHASAN}

Penangkapan Ubur- Ubur di wilayah Teluk Saleh Kecamatan Empang Kabupaten Sumbawa biasanya mengalami perpindahan Ubur-Ubur, jenis Ubur- Ubur yang terdapat di Teluk Saleh adalah 
Ubur-Ubur merah atau yang disebut C. mastigophora yang memiliki kemampuan bergerak dengan tentakel, namun juga Ubur- Ubur tersebut masih mengikuti pergerakan arus laut, arus pasang surut dan angin laut untuk penyebaran horizontal, perpindahan Ubur- Ubur tersebut berpengaruh terhadap jangkauan nelayan yang juga berubah-ubah setiap waktu selama 3 hingga 4 bulan berkisar antara bulan September hingga Desember atau Januari hingga Februari. Pergerakan migrasi Ubur-ubur dari sekitar pantai selatan menyeberangi Teluk Saleh hingga pantai utara pesisir gunung Tambora mengikuti pergerakan arus dan konsentrasi makanan (Eriksen et al., 2012). Teluk Saleh termasuk dalam kawasan pengembangan wisata dan konservasi alam yang memiliki potensi sumberdaya yang dapat menjadi nilai ekonomi bagi kehidupan masyarakat nelayan Teluk Saleh.

Teluk Saleh terletak diantara dua Kabupaten yaitu Kabupaten Sumbawa dan Kabupaten Dompu yang merupakan perairan semi tertutup dan berhubungan langsung dengan Laut Flores (Wasilun., 2006). Teluk Saleh seluas $2.123 \mathrm{~km}^{2}$ terletak di Pulau Sumbawa yang merupakan salah satu pulau di Provinsi Nusa Tenggara Barat, adapun pada bagian timur wilayah teluk adalah wilayah administrasi Kabupaten Dompu. Rata-rata penduduk yang berada di pesisir Teluk Saleh merupakan penduduk yang berasal dari suku Bugis. Ubur- Ubur adalah sejenis binatang laut yang tidak bertulang belakang dan termasuk dalam Filum Cnidaria, Ubur- Ubur yang dimaksud adalah hewan dari kelas Schypozoa, sehingga sering disebut Ubur-Ubur. Schypozoa pertama kali dieksploitasi pada tahun 2006 di Teluk Saleh oleh nelayan yang tinggal di wilayah sekitar Teluk Saleh Kabupaten Sumbawa, sedangkan nelayan dari Kabupaten Dompu yang menetap di sekitar pantai Teluk Saleh pertama kali melakukan aktivitas menangkap Ubur-Ubur pada tahun 2009. Nelayan Teluk Saleh melakukan operasi penangkapan Ubur-Ubur mulai dari sore hingga pagi hari dengan menggunakan 
scoop-net, lampu dan perahu kayu sejak 2006 hingga saat ini. Nelayan menjual hasil tangkapannya yakni Ubur-Ubur kepada pembeli yang memiliki unit pengolahan Ubur- Ubur dan tersebar di pantai daratan sekitar kawasan Teluk Saleh. Schypozoa hanya diproses bagian mulutlengan (mulut-kaki). Sumber daya perikanan ini menjadi penting karena jika populasi Schypozoa meningkat (mekar) maka semua nelayan di wilayah Teluk Saleh beralih menangkap Ubur-Ubur sebagai tambahan pendapatan rumah tangga nelayan tersebut. Komunitas pesisir Teluk Saleh terutama perempuan juga terlibat dalam kegiatan memancing atau menangkap Schypozoa dan melakukan pelepasan bagian mulut-lengan serta bekerja pada pemrosesan Ubur-Ubur.

Berdasarkan hasil wawancara salah seorang nelayan Ubur- Ubur Teluk Saleh Bapak Syarif yang tertuang pada pernyataan berikut;

"....fenomena kemunculan Ubur- Ubur ini sebenarnya sudah cukup lama, tetapi belum ada pembeli yang mau membeli Ubur-Ubur, kami juga tidak tau cara mengolah Ubur-
Ubur ini, jadi kami biarkan saja Ubur- Ubur itu, bahkan dianggap sebagai hama oleh nelayan karena mengganggu aktivitas mereka menangkap ikan di laut, pada Tahun 2006 barulah ada masuk pembeli dari luar daerah, sejak saat itu hampir semua nelayan yang ada di wilayah Teluk Saleh ini menangkap UburUbur untuk menambah penghasilan mereka, mereka tidak lagi menganggap UburUbur ini sebagai hama, bahkan sudah menjadi kegiatan rutin mereka ketika musim Ubur- Ubur tiba....."

Kemunculan Ubur-Ubur terlihat sejak bulan Agustus hingga September, akan tetapi pada awal kemunculan tersebut nelayan tidak menangkap UburUbur, disebabkan Ubur-Ubur tersebut masih kecil dan terlalu muda dan pada bulan November nelayan Teluk Saleh mulai memburu Ubur-Ubur di wilayah Teluk Saleh hingga Desember, namun beberapa nelayan masih memburu Ubur-Ubur hingga bulan Januari dan Februari, tergantung pada stok Ubur-Ubur yang terdapat di permukaan laut.

Hal ini dapat terjadi akibat adanya angin musim barat, yang biasanya datang pada akhir tahun atau pada bulan Desember, 
sehingga nelayan kembali memburu Ubur- Ubur pada Bulan Januari hingga Februari. Upaya penangkapan Ubur-Ubur juga bergantung pada musim dan cuaca. Sebanyak 80 hingga 100 perahu nelayan masing-masing 5 Gross Ton (GT) yang beroperasi menangkap Ubur-Ubur dari Desa Sor Dompu dan Desa Labuan Jambu Sumbawa setiap malam selama musim kemunculan Ubur- Ubur. Trip perjalanan penangkapan Ubur- Ubur dari Desa Soro hingga ke lokasi penangkapan membutuhkan waktu 90 hingga 120 menit. Lokasi tangkap Ubur-Ubur selalu berpindah pindah dari daratan arah selatan hingga ke pantai utara ke pesisir Gunung Tambora. Hingga saat ini belum ada informasi tentang kapan dan seberapa jauh serta apa yang mempengaruhi migrasi populasi Ubur-Ubur menyeberangi perairan Teluk Saleh.

Sumber Daya Manusia, bukan hanya tentang skill atau kemampuan yang harus dimiliki nelayan, tetapi penting juga menjaga kesehatan, karena ketika tubuh tidak sehat maka tentu nelayan tidak dapat melakukan aktivitas menangkap Ubur-Ubur, mengingat bahwa cuaca sering tidak menentu yang dapat menyebabkan nelayan mengalami gangguan Kesehatan, hal ini pastinya berdampak pada pendapatan rumah tangga nelayan akan berkurang. SDM tentu menjadi faktor utama keberhasilan nelayan dalam melakukan aktivitas menangkap Ubur-Ubur, disamping nelayan harus memiliki skill atau kemampuan dalam upaya menangkap Ubur-Ubur juga harus menjaga kesehatan karena serungnya bermalam dilaut tentu berpengaruh pada kesehatan nelayan, untuk itu penting sekali nelayan tetap menjaga kesehatan agar tubuh tetap prima dan mendapatkan hasil tangkapan yang banyak. Dalam hal ini peneliti mencoba menggali informasi lebih dalam dan adapun hasil wawancara bersama Bapak Sukardi salah satu nelayan UburUbur Teluk Saleh yang tertuang pada pernyataan berikut:

".....kami

hanya mengandalkan kemampuan yang ada saja, kami tidak punya kelebihan apapun dalam menangkap ikan ataupun Ubur- Ubur, kami 
hanya bermodal sehat agar kami bisa bertahan dilaut dengan cuaca yang terkadang tidak mendukung, hujan, ombak juga dinginnya ditengah laut tentu membuat kami bisa sakit, untuk itu kami tetap menjaga kesehatan kami agar kami tetap bisa melaut menangkap UburUbur, begitu pula melempar jaring juga harus teliti, karena bisa saja ketika salah melempar jaring maka UburUbur nya tidak dapat ditangkap, ketika badan kita sehat maka tentu kita punya tenaga untuk melempar jaring dengan baik supaya UburUbur nya bisa ditangkap...."

$\begin{array}{ccc}\text { Bapak } & \text { Sukardi } & \text { juga } \\ \text { menambahkan } & \text { bahwa } & \text { SDM }\end{array}$
penting juga untuk mendapatkan hasil tangkapan Ubur-Ubur yang banyak. Penangkapan Ubur-Ubur menggunakan serok panjang untuk mempermudah jangkauan ke perairan dan dapat juga menggunakan jaring, hal ini membutuhkan skill dalam menangkap Ubur-Ubur dengan tubuh yang kuat dan sehat tentu nelayan bisa mendapatkan hasil tangkapan sesuai dengan usahanya. Seperti kutipan pernyataan berikut;

“....menangkap Ubur-Ubur itu gampang- gampang susah, kalau badan kita tidak kuat atau sakit mana mungkin bisa melempar jaring apalagi menggunakan serok panjang untuk memudahkan jangkauan ke perairan, maka itu kami nelayan di Teluk Saleh jika cuaca tidak mendukung maka kami tidak menangkap Ubur- Ubur, kami takut juga ada apa- apa di laut, kami akan melakukan tangkapan Ubur- Ubur lagi setelah cuaca membaik, hasil tangkapan kami tentunya sesuai dengan usaha kami...."

Berdasarkan pengamatan peneliti bahwa Sumber Daya Manusia dalam hal ini yang utama yang menjadi faktor penting dalam upaya menangkap Ubur- Ubur adalah menjaga kesehatan sehingga nelayan penangkap Ubur-Ubur dapat melakukan aktivitas melaut menangkap atau menjaring Ubur-Ubur, dengan tubuh yang sehat nelayan Teluk Saleh dapat menggunakan tenaganya untuk melempar jaring dan menggunakan serok panjang guna memudahkan jangkauan ke perairan, hal ini tentu membutuhkan tenaga yang kuat dan sehat.

Arus yang pasang surut juga mempengaruhi arah Ubur-Ubur, nelayan akan mengikuti kemana pergerakan arus membawa Ubur- 
Ubur tersebut, maka kesanalah arah perahu nelayan sehingga dibutuhkan konsentrasi agar nelayan dapat mengikuti arah arus laut membawa perahu mereka. Menurut Aryanto (2019) pergerakan arus di Teluk Saleh dipengaruhi oleh arus pasang surut, yang mana pada malam hari cenderung kearah barat dan utara atau ke mulut Teluk, sehingga konsentrasi ubur-ubur cenderung menjauh ke barat atau ke utara.

Berdasarkan pengamatan ini pula maka peneliti dapat menarik kesimpulan bahwa SDM dapat mempengaruhi hasil tangkapan nelayan Ubur-Ubur, ketika nelayan Ubur-Ubur mendapatkan hasil tangkapan yang banyak dapat menambah penghasilan rumah tangga nelayan Ubur- Ubur itu sendiri, begitupun sebaliknya bahwa ketika nelayan tidak dapat melakukan aktivitas memburu Ubur-Ubur maka penghasilan rumah tangga nelayan akan berkurang karena sebagian besar nelayan Teluk Saleh menggantungkan nasibnya pada usaha melaut atau menangkap ikan dan memburu Ubur-Ubur untuk menambah pendapatan rumah tangga nelayan tersebut.

Untuk meningkatkan kesejahteraaan nelayan UburUbur Teluk Saleh selain strategi dalam meningkatkan dan menjaga kualitas SDM, strategi selanjutnya yang penting juga dalam upaya peningkatan kesejahteraan nelayan Ubur- Ubur Teluk Saleh adalah pada modal. Untuk melakukan aktivitas melaut nelayan Ubur-Ubur, harus memiliki modal karena adanya pembiayaan pelayaran penangkapan atau memburu Ubur-Ubur.

Komponen pembiayaan dalam upaya penangkapan Ubur- Ubur untuk satu kali trip melaut dalam satu malam membutuhkan biaya bahan bakar (BBM Solar) sebanyak 20 hingga 35 Liter dengan pengeluaran antara $\mathrm{Rp}$ 200.000-350.000, untuk biaya bensin genset lampu listrik $\mathrm{Rp}$ 50.000-80.000. Sementara kebiasaan merokok tidak bisa terhindarkan, sehingga masuk dalam biaya modal 3 hingga 5 bungkus rokok dalam semalam seharga Rp 150.000. Adapun biaya makan malam untuk 7 
orang dalam satu perahu sebesar Rp 175.000, dan biaya lain-lain diproyeksikan $\mathrm{Rp} \quad 150.000$ sehingga total modal yang harus dikeluarkan dalam trip melaut per malam sebanyak Rp 725.000 hingga sebesar Rp. 905.000. Sarana dan prasarana penunjang juga penting untuk diperhatikan oleh nelayan seperti perahu, jaring dan lainnya yang dibutuhkan untuk memburu Ubur-Ubur. Seperti kutipan pernyataan Bapak Syarif berikut ini;

“....Rata-rata pengeluaran berkisar Rp. 700.000 hingga 900.000 kurang lebihnya segitu setiap malam saat kami memburu Ubur- Ubur dan nanti hasilnya juga kami bagi, untuk pemilik kapal mendapatkan 30-40 persen, 10 persennya dibagi rata untuk yang lainnya. Besaran persen untuk pemilik kapal juga termasuk mengganti biaya rokok, makan, bensin, solar dan biaya lainnya. Sedangkan banyaknya nelayan yang memburu UburUbur juga berpengaruh sama hasl yang kami dapat, mangkanya kami butuh konsentrasi dan mengikuti arah arus laut, karena UburUbur itu akan pergi kemana pergerakan arus membawanya....."

Berdasarkan pengamatan peneliti bahwa tidak cukup hanya
SDM saja sebagai strategi dalam upaya peningkatan kesejahteraan nelayan pemburu Ubur-Ubur di Teluk Saleh, mereka juga membutuhkan modal untuk melakukan aktivitas memburu Ubur-Ubur, modal tersebut sebagai penunjang kegiatan nelayan tersebut, mereka memburu Ubur- Ubur hampir setiap hari mulai dari sore hingga malam hari, maka mereka harus menyiapkan modal yang dibutuhkan selama kegiatan memburu Ubur-Ubur, faktor inilah yang menjadi penyemangat mereka untuk memburu UburUbur dalam jumlah yang banyak sehingga mereka tetap memiliki modal untuk melaut dan bisa menambah pendapatan rumah tangga mereka. Berdasarkan hasil wawancara bersama Bapak Syarif seperti kutipan pernyatan berikut; “....misalkan pendapatan $R p$. 7.000.000 maka 30-40 persen untuk mengganti biaya modal dan pemilik kapal sebesar antara $R p$. 2.100.000 hingga Rp. 2.800.000, dan sisanya dibagi sama- sama 10 persen berkisar antara Rp. 600.000 hingga Rp. 820.000. dibanding dengan gaji dari jenis pekerjaan yang lainnya....." 
Selain SDM dan modal, strategi yang tidak kalah penting juga sebagai upaya dalam meningkatkan kesejahteraan nelayan Teluk Saleh adalah karakteristik produk, hasil tangkapan Ubur-Ubur juga mempengaruhi pendapatan nelayan. Ubur-Ubur yang kecil dan masih muda, belum waktunya untuk dipanen, maka nelayan Ubur-Ubur harus menunggu sampai Ubur-Ubur itu siap dipanen, nealayan harus menunggu hingga bulan November karena Ubur-Ubur tersebut sejak bulan Agustus sudah mulai bermunculan kepermukaan air laut, namun karena belum waktunya dipanen maka harus menunggu hingga memasuki bulan November hingga Desember bahkan jika pada bulan Desember terjadi cuaca yang tidak bersahabat maka nelayan pemburu Ubur-Ubur akan kembali memburu Ubur-Ubur pada bulan Januari hingga Februari.

Penjualan Ubur-Ubur dihitung berdasarkan jumlah keranjang. Setiap keranjang dihargai secara bervariasi berdasarkan musim. Jika diawal musim, harga satu keranjang Ubur- Ubur berkisar antara Rp 70.000 - 100.000. Harga terendah Rp 70.000 tercatat di awal musim penangkapan di bulan November. Pada Bulan Desember mencapai harga Rp 90.000-100.000 per keranjang dan pada bulan Januari dan Februari ini kembali ke harga Rp 70.000 - 80.000. berdasarkan hasil wawancara peneliti bersama nelayan Ubur- Ubur di Teluk Saleh bahwa pada bulan Desember sering mengalami musim angin barat di sekitar Teluk Saleh cuaca tidak mendukung untuk memburu Ubur-Ubur, angin mulai kencang dan cuaca tidak menentu, sehingga banyak nelayan yang tidak dapat memburu Ubur-Ubur. Jumlah Ubur-Ubur yang dapat ditangkap jumlahnya sedikit, sehingga harga Ubur-Ubur menjadi meningkat pada bulan Desember. Seperti teori ekonomi hukum pasar, bahwa jika persediaan barang berkurang sedangkan kebutuhan tetap dan permintaan meningkat, maka harga yang ditawarkan juga akan meningkat.

Sistem penjualan Ubur-Ubur berlangsung pada malam hari di 
lokasi penampungan pusat pembelian. Lokasi penjualan Ubur- Ubur di Desa Labuan Jambu Kabupaten Sumbawa. Ada dua cara atau sistem pembayaran Ubur- Ubur; Pertama, Ubur- Ubur yang disetor atau dijual pada malam itu kepada pembeli atau perwakilan dari suatu perusahaan pengepul Ubur- Ubur, nelayan tidak langsung menerima uang dari perwakilan perusahaan pengepul tersebut, melainkan nelayan yang menjual UburUburnya diberi kupon dengan catatan sejumlah keranjang yang disetor oleh nelayan. Pembayaran akan diberikan pada keesokan harinya tepatnya pada sore hari, dan ini sudah menjadi kesepakatan antara perusahaan pengepul dengan nelayan yang menjual Ubur-Uburnya kepada pengepul tersebut.

Cara Kedua, jika nelayan menginginkan uang cash pada malam itu, maka nelayan tersebut akan menjual Ubur- Uburnya pada pembeli lain yang bukan dari perusahaan pengepul, pembeli tersebut juga berasal dari daerah luar dan akan membayarkan cash kepada nelayan tersebut sebanyak jumlah keranjang UburUbur yang didapat, namun setiap keranjang dipotong $\mathrm{Rp} 1000$ sebagai keuntungan bagi pembayar cash. Cara kedua ini banyak dipilih oleh nelayan agar tidak menunggu pembayaran keesokan harinya. Jika satu perahu berhasil menjual 70 keranjang, maka pendapatan kotor 70 keranjang per $\mathrm{Rp} \quad 60.000$ menghasilkan pendapatan terendah $\mathrm{Rp}$ 4.200.000. Namun jika harga maksimum pembelian mencapai Rp 100.000 per keranjang, maka pendapatan kotor mencapai 7.000 .000 per malam untuk setiap perahu nelayan pemburu Ubur- Ubur.

\section{KESIMPULAN, IMPLIKASI DAN KETERBATASAN PENELITIAN}

Kemunculan Ubur- Ubur di pulau Teluk Saleh Kabupaten Sumbawa, merupakan sebuah peluang untuk mengembangkan produk ini bukan hanya mengekspor material baku, akan tetapi berupa material olahan agar memiliki nilai tambah yang lebih besar dari sekedar bahan baku. Ubur- Ubur yang ditemukan di Teluk Saleh sudah sejak tahun 2006 dieksploitasi oleh nelayan karena permintaan dari 
Negara luar seperti Cina. Sejumlah besar nelayan sudah mendapatkan benefit dari usaha penangkapan Ubur- Ubur di pulau Teluk Saleh. Namun yang lebih penting adalah seberapa banyak populasinya sehingga dapat diprediksi volume bisnis. Apabila volume Ubur- Ubur dapat diketahui, lalu bagaimana cara pemanfaatannya, Berbagai metode pengolahan Ubur- Ubur, namun masih menggunakan material garam yang banyak dan memakan waktu yang cukup lama. Setelah produk Ubur- Ubur jadi, kemanakah akan dijual dan bagaimana pengelolaan badan usaha dalam sistem perdagangannya. Potensi Ubur- Ubur di pulau Teluk saleh belum dapat diketahui secara pasti, kapan dan berapa lama serta seberapa besar potensi yang dapat dimanfaatkan.

Untuk pemanfaatannya dibutuhkan proses yang baik, efisien, higienis dan aman untuk kesehatan sesuai standar. Tehnologi yang digunakan juga masih manual yang dapat pula terhambat oleh cuaca buruk. Industrialisasi skala besar menjadi tantangan untuk dikembangkan guna ketahanan pangan dan diversifikasi pangan, bahan baku obat-obatan dan functional food.
Implikasi penelitian ini berdasarkan temuan bahwa UburUbur dimanfaatkan oleh nelayan lokal pulau Teluk Saleh untuk dieksploitasi guna mendapatkan penghasilan dan dapat meningkatkan kesejahteraan rumah tangga nelayan. Pemanfaatan Ubur- Ubur di Teluk saleh dapat memberi dampak positif. Hal ini disebabkan bahwa Ubur- Ubur yang biasanya dianggap sebagai hama penyengat dapat menjadi komoditas ekspor Teluk Saleh yang mempunyai nilai dan harga jual yang tinggi, terlebih lagi hasil laut di Teluk Saleh cukup berlimpah, sehingga menjadikan masyarakat nelayan pulau Teluk Saleh Kabupaten Sumbawa dapat mengoptomalisasi benefit sehingga berkecukupan dan sejahtera.

Adapun keterbatasan dalam penelitian ini bahwa hasil penelitian ini hanya berlaku dalam satu periode waktu, yaitu pada saat penelitian berlangsung. Oleh karena itu hasil penelitian ini tidak dapat menggambarkan kondisi yang sama pada tahun berikutnya atau pada masa yang akan datang. Terkait lokasi penelitian, diinterpretasikan sebatas pulau Teluk Saleh Kecamatan Empang Kabupaten Sumbawa. 


\section{REFERENSI}

Andarsari, P. R., \& Ningtyas, M. N. (2019). The Role of Financial Literacy on Financial Behavior. JABE: Journal of Accounting and Business Education, 4(1), 24-33. https: / / doi.org/10.26675/jabe.v $4 \mathrm{i} 1.8524$

Asrial, E., Prajitno, A., Susilo, E., \& Bintoro, G. (2015). RAPJELLYFISH Method to evaluate the sustainability status of edible jellyfish resource management in the Saleh Bay, Indonesia. International Journal of Recent Scientific Research.

Badan Pusat Statistik. (2015). Garis Kemiskinan, Jumlah dan Persentase Penduduk miskin Kabupaten Sumbawa.

Bronsteen, J., Buccafusco, C., \& Masur, J. S. (2010). Welfare as happiness. Georgetown Law Journal.

Departemen Kelautan dan Perikanan. (2000). Kebijakan dan Program Pemberdayaan Sosial Ekonomi Masyarakat Pesisir, Pantai dan Pulau- Pulau Kecil, Semarang.

Dinas Kelautan dan Perikanan. (2003). Data Kelautan Indonesia.

Eriksen, E., Prozorkevich, D., Trofimov, A., \& Howell, D. (2012). Biomass of scyphozoan jellyfish, and its spatial association with $0-$ group fish in the barents sea. PLoS

ONE. https://doi.org/10.1371/journal. pone.0033050

\section{Gunawan. (2010). Kontribusi Organisasi Sosial Dalam Pembangunan Kesejahteraan Sosial. P3KS Press.}

Indrayani, L. (2020). Makna Literasi Keuangan dalam
Keberlangsungan Usaha Industri Rumah Tangga Perempuan Bali. JIA (Jurnal Ilmiah Akuntansi).

Kasryno, F. (2004). Prospek Pengembangan Ekonomi Pedesaan Indonesia. Yayasan Obor Indonesia.

Manullang. (2012). Dasar-dasar Manajemen. Gadjah Mada University Press.

Morissan, A. M. (2012). Metode Penelitian Survei. Kencana.

Qashidi, H. (2019). Analisis Perlakuan Akuntansi Aset Biologis (Studi Kasus Pada Koperasi Agro Niaga Jabung).

Rambe, A. (2004). Alokasi Pengeluaran Rumah Tangga dan Tingkat Kesejahteraan (Kasus di Kecamatan Medan, Kota Sumatra Utara).

Riefsa. (2014). Potensi Kelautan Indonesia Bagi Kesejahteraan. CV. Aryheaeko Sinergi Persada.

Solihat, S. H. (2004). Pemanfaatan Ubur-Ubur (Aurelia sp.) Sebagai Salah Satu Upaya Diversifikasi Pembuatan Kerupuk Ikan Fakultas Perikanan dan Ilmu Kelautan, Institut Pertanian Bogor.

Umar, H. (2008). Strategic management in sction: Konsep, teori, dan teknik menganalisis manajemen strategis strategic business unit berdasarkan konsep Michael R. Porter, Fred R. Gramedia Pustaka Utama.

Wasilun., M. \&. (2006). Kondisi oseanografi di perairan Teluk Saleh, Nusa Tenggara Barat. Prosiding Seminar Nasional Ikan IV. Kerjasama LRPSI, LIPI, dan MII. 